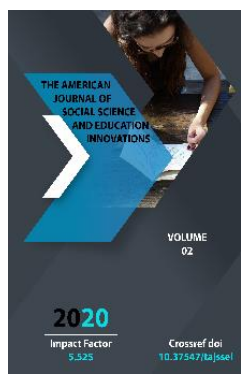

\title{
The Belief And Faith Of The Iranians
}

\section{Oydin Turdiyeva}

Doctor Of Philological Sciences Of Tashkent State University Of Oriental Studies, Uzbekistan

Copyright: Original content from this work may be used under the terms of the creative commons attributes 4.0 licence.

\section{ABSTRACT}

What are superstitions, beliefs and convictions? Is it the result of human experience as a result of observations or the ability to read celestial signs? In fact, it doesn't matter. What is important is the presence of these symptoms. But it is also not right to destroy the centuries-old experience of the people. Of course, not all myths can be trusted. This article covers the mysteries and beliefs of the various peoples living in Iran.

\section{KEYWORDS}

Customs, superstitions, mythological notions, tribes.

\section{INTRODUCTION}

Each nation has its own customs, traditions and rituals. Each of them is radically different from the other. One is beneficial, one is absolutely harmful. Our goal is not to talk about whether these superstitions are beneficial or harmful, but to study the superstitions and folk beliefs that are part of the folklore of the Iranian peoples. 


\section{MATERIALS AND METHODS}

Along with the traditions, beliefs and superstitions of the Iranians, there are countless mysteries. The myths within a nation that have been preserved for centuries are in fact derived from the way of life, culture, and environment of that nation. The beliefs of the people, which embody the ancient traditions of the Iranian people, resonate with the mythological ideas, beliefs, lifestyle and spirituality of the Iranian people. The beliefs of different tribes and ethnic groups living in different parts of the country also vary. For example, according to the belief of the Qashqai (Located near the Persian Gulf, one of the southern provinces of the country, the Qashqai are a nomadic Turkic-speaking tribe living here), if a tribe does not have a weapon, it means that it is equal to a woman without clothes. Again, according to their belief, a horse is like a foot. A grazing or migratory squid is equated with a dehydrated fish. It is believed that if a pregnant woman sees a headscarf in a dream or wears a headscarf on her head, will give birth to a baby girl. If they want to come to an agreement on any condition in the desert, they put a few stones on top of each other, call this column "Hazrat Abbas's donkey" and swear by the name of Hazrat Abbas. Once the deal is over, they break the stones and tell each other that it is impossible to break the deal. Thus, the agreement is made without any written documents. They believe that faithfulness to the word spoken and the oath sworn is above all else.

According to the Mashhad (Mashhad is the administrative center of Khorasan Razavi Province. (It is the second largest city in Iran after Tehran in terms of population and size. It is the holy city of Shia Muslims) doctrine, if a person eats onions on Saturday, he will become rich. If a person returns late from a journey, they raise their broom upside down towards the qibla, believing that this will help the person on the journey to return home faster. They think it's crazy if someone goes to the bathroom on Sunday. Anyone who buys food on Friday night and brings it home will be a blessing in disguise. If the donkey is sitting and snoring, it is believed that the death of the owner is imminent. Seeing a white horse in the afternoon or on the right is a sign of the formation of desires according to the beliefs of the Mashhadites. The people of Quchon (A city in northeastern Iran) people they count like "one round, two rounds, three ...". If a broom touches someone's foot, a stick is broken from it. According to their superstition, this way the misfortune will be prevented. They also think that sweeping in the evening is not a good feature. Putting it in front of someone with a bowl turned on a plate is a sign of disrespect.

Deregezians (Derregez is a city in the northeast of the country, on the Razavi Khorasan plateau) believe that if a crow is knocking on the roof or wall with its beak in the early morning, the good news will come or a longawaited visitor will come. They do not sit on the threshold with the belief that they will not be slandered. They believe that if a man passes between two women, happiness will not smile, and a ring with an agate stone will bring happiness. If a hen crows like a rooster, the owner will quickly slaughter it, calling it a sign of misfortune.

In the village of Targawar in western Azerbaijan, Iran, it is believed that if a man passes under a spinning wheel, it is a disgrace, or if a man eats the first loaf of bread from the oven, his wife will die. If a person wants to get coals under boiling milk, the owner of the pot will not like it and will say that the milk of his 
sheep will be without blessing. It is believed that if a turtle bowl and a shell is put in a butter mesh, its blessing will increase, and when the wolves attack, they hang the hoof of a deer around the sheep's neck so that it can run as fast as a deer.

The beliefs of the people of Erdeston, located on the outskirts of Isfahan, are also very unique. For example, they believe that if the wind blows from the north, the air will be dry and cold, and if it blows from the south, the air will be hot. It is said that if the star of Suhayl falls on a girl's face (as seen by a girl), she will have a beautiful, white face, and if this star falls on a any fruit, it will taste sweet and the color will be clear. It is believed that if the Venus star rises after sunset on the west side or on the Carcass Mountains (Mountain ridges in the northwest of Isfahan), it will be wet and rainy this year. In addition, the Erdestonians consider the round flanges around the moon to be a sign of precipitation. If the old clouds give way to new clouds, or if the clouds cover the middle of the mountain, the top and bottom of the mountain are said to be open. It is said that on cloudy days, crows land on the roof, sing and jump in the backyards, which is a sign of snowfall. If it is raining lightly, it is still a sign of prolonged rain. If there is lightning, thunder, and then rain, it is a sign of a fertile year ahead, otherwise, if there is no rain after lightning, there is a drought, and if a gray cloud covers the sky, it is a sign of snow. If the sound of jackals comes at night, it means that the weather will be clear the next night. Thus, the beliefs of the Erdestonians in relation to natural phenomena and astronomical objects are very specific, and some of them can be observed in the beliefs of other peoples, especially the Uzbek people. For example, if the sky is covered with clouds at night and the wind is strong, it will not be very cold. The stronger the wind, the less likely it is to be cold. If the stars begin to twinkle in the night sky in late autumn, a strong wind will blow and the air will cool. When it rains, there is a strong wind, which means that the air is clear. In the fall, when the sun sets and the sun rises, it rains when the sun is dark red. If the geese fly away, it will snow soon. If the sparrow is bathing in the pond, the days will be hot, and if the crow is bathing, it will be a rainy day. If the moon is bright - the day will be clear, if it is dark, dim, it will rain. When the clouds line up, the sun warms. If the crows sit on the high branches of the tree - cold air, if they sit on the lower branches - the windy air. If it rains in large chunks, it won't last long. The main sign that the weather is good is that the sky is covered with a flat gray cloud. The stronger the wind, the weaker the cold. During the day the weather is dark and when the sun is red towards sunset, it rains. As we have witnessed, the myths between the two peoples are very similar. There is a wonderful custom in the village of Bor, located in Nishopur if someone comes across a wheat bush where two ears of corn are joined together during the wheat harvest, they leave that bush unharvested. After harvesting all the wheat crop around him, the landowner brings a sheep and rotates it three times around the leftover wheat and then sacrifices the sheep near that wheat field. Its meat is distributed among the villagers. Creatures believe that this way, that is, through sacrifice, next year's harvest will be more and more productive.

The traditions of the Sanjabis, a Kurdish tribe living in Kermanshah, are also unique: if a cat with dirt gets into the house, it means that a stranger is coming to the house; if someone bites his cheek from the inside, someone else is 
gossiping about him/her somewhere else; getting married on a Saturday, going on a trip is a no-brainer; it is believed that if a Navruz meal is spilled on the floor in a house, the family will not be able to get rid of grief and frustration until the end of the year.

The population of Kalhor, another Kurdish tribe living in Kermanshah, considers a year to be 360 days, not 365 days. The remaining five days are considered superfluous and are called "paws". Panja Farvardin begins on the 14th of the month and ends on the 18th at sunset. During these days, the Kalhors do nothing. These tribes postpone treats, weddings, visits, hospitality, and other similar activities during these days. The women, whose children are boys and who have died, cook eggs, paint them in colors, and distribute them to the children in the cemetery.

In the west of the country, in the areas bordering Iraq, live the tribes of Elam. The majority of the population is predominantly Kurdish.

Their beliefs and superstitions also differ from those of the above Kurdish tribes. For example, if a hunter sees a crow at the beginning of the street, he will return from the hunt luckily, and if he sees a rabbit, he will return from the hunt empty-handed. Such myths are not alien to our people either. In particular, when a tourist wolf sees an eagle, he considers himself lucky. When he sees the fox, he becomes suspicious and waits for something unfortunate to happen. The Elamites consider fig and olive trees sacred and do not cut them down. They consider eating pomegranate to be a good deed. Pomegranates are donated on Friday evenings in memory of the past. They wear a red stone jewelry around their necks in the belief that it will relieve their pain. There is a type of pearl barley that is put in a bowl of flour - to make it flourish. . It is believed that if a dog or cat is sprayed with water, the person who sprayed it will get a sore on his hand. It is believed that if a dog barks long like a wolf on winter nights, it will snow that night.

The mysteries of the tribes living in the province of Mamasani in the Persian Gulf are also very interesting. For example, it is said that if a person is sick and a fox enters his dream and calls him, the patient will die. But to prevent this from happening, the Iranians turn their shoes, which are made of woven fabric with a unique sole, into the opposite, and say, "Stick from us, meat from you." Then they believe there will be no death. When the sun and moon are eclipsed, they believe that the higher powers have taken away the moon and the sun. They play drums, shoot arrows, make different sounds to free the sun and the moon. Mamasani women believe that there is a demon that scares and beats women during childbirth. To prevent this, they throw a black rope made of goat wool all around the room and also wrap it around the front of the room door.

They also hang a sheep's heart and kidneys in front of the door of the room, and a knife, salt, onion, and donuts next to them. The woman who gave birth and the baby are scratched black so as not to be damaged, as if sealed on the forehead. In addition, whiteness - flour, salt, etc., it is impossible to take the fire out of the house at night. Men don't have to stand there while the women of the Bachakchi tribe in Kerman are baking bread and chasing milk to get butter. That is, men cannot be present in the process of these things. The members of this tribe do not harvest some of the wheat, barley and some other legumes during the 
harvest. At the end of the harvest, all the harvesters wrap and share this part left behind.

Then each reaper takes these harvested things home from a few spikes and hangs them on the walls of their houses and tents.

According to their belief, these spikes are divine spikes and bring blessings. The people of Seystan also have wonderful myths. For example, if someone sprays water on a dog, it will wither. If someone drives an animal other than a rooster or a chicken as a "kish-kish," a visitor comes to his house. It is believed that if a cow shakes its foot, it will rain. If you sprinkle salt on the fire, the rain will stop. If the wind doesn't blow in the summer, the family's eldest son's pants (regardless of his age) are hung upside down on a long stick, believing that the wind will blow after that.

Another of their wonderful customs is that if two snakes cling to each other, the eldest son of the family takes off his pants and throws them on the snakes, and after the snakes separate, the boy wears a bead, which the locals call "mura".

According to the Seyyans, the person who wears this bead is lucky.

Furthermore, if a pregnant woman's voice touches a snake's ear, the snake's eyes become blind; if someone witnesses the horse returning to the rumen at the turn of the year, they believe he will die by the end of the year. As we can see, these myths are amazing. According to the Momash (Momash is the name of one of the Iranian Kurdish tribes) tribe in Oshnuyeh, a town in western Azerbaijan, it is unfortunate to go to a spring at night, give salt to someone in the afternoon, or take a black pot to the sheep. According to Sangsar (It is the ancient name of Mehdishahr, located on the Semnon plateau, and the inhabitants of the land speak the Sanskrit language) residents, old women lie in the bride and groom's bed the day before the wedding to live longer, which they believe will prolong their lives. It is believed that sweeping at night will damage a person's property.

According to the Bakhtiari tribes (The Bakhtiaris speak in the Bakhtiari dialect, one of the dialects of the Lur language) of southwestern Iran, if a wolf's eye accompanies someone as a tumor, it is believed that the person will not suffer from any disease. It is also believed that if a wolf's leg is tied to a newborn's cradle, the baby will not get sick and will not be touched by the eye. Until recently, similar customs existed in some districts of Kashkadarya region. It was customary to put wolf skin under the cradle of a newborn baby and to decorate the cradle by piercing its teeth.The people of Elam (Elam is a city in western Iran, bordering Iraq, where the majority of the population is Kurdish) have a wonderful legend about the distribution of life to humans and animals. According to it, after God created man, He created a donkey and a dog to lighten his weight.

When the donkey asked God about his mission, he said that God had given him thirty years of life and during that lifetime he had been given the task of carrying the heavy burdens of man. The donkey begged God to shorten his troubled life. God accepted his will and shortened his life from thirty to ten years. The dog then asked God about his mission. He was also told that he had been given thirty years of life, during which time man should guard his property, his house, stay awake at night and stay awake during the day. The dog also begged to shorten his life from such hardships, and God accepted this as well. The dog was 
also given ten years of life. The man then asked God about his mission, and God told him that he, too, had been given thirty years of life, and that he would live a full life during that time, and that the dog and the donkey would be at his service.

And Adam begged God to prolong his life, saying that thirty years would not be enough. Then God has forty years left of the life of a donkey and a dog, and if you will, I will add these forty years to the life given to you. Mankind has accepted this, and since then the human race has spent the first thirty years of its life without sorrow and joy, and the rest of its life as a dog and a donkey.

When the Elamites see the Milky Way, they call it the Meccan Way. Some call the Milky Way the pillar of heaven.

In conclusion, it can be said that many of the above habits can be counted. It's even harder to get to the bottom of the count. As we try to understand how such superstitions and beliefs came to be. We witness that man has always tried to find aspects of himself that are of interest to him from every event.

Man imaginary seeks a reason to substantiate these interests. Over time, the experience of life makes it necessary to divide these events into species, to distinguish between useful and harmful.

\section{CONCLUSION}

As a result, in the minds of the people there are judgments: "this is good, this is bad." For example, it is good if a nightingale sings in a person's yard; the assumption that an owl sings is bad. At first glance, this seemingly insignificant situation has been formed in the minds of nations, including the Iranian people, over the centuries as the basis for various traditions and customs.

\section{REFERENCES}

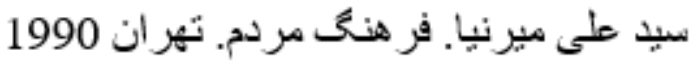

بهلوان كجل. كالونو. لنبيخر اد. 1928

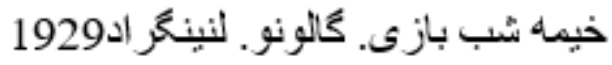

. كاللونو. لنينگ اد1927 زورخانه

I.S.Braginsky. Iranian literary heritage.

Moscow 1984.

https://uzbolakay.ucoz.com/ 